\title{
Seftarolin, Antibiotik Baru dengan Aktivitas Anti-MRSA: Sebuah Kajian Efektivitas, Keamanan, dan Biaya Penggunaan
}

\section{(Ceftaroline, a New Anti-MRSA Antibiotic: a Review of the Efficacy, Safety, and Cost of Utilisation)}

\author{
Steven Victoria Halim ${ }^{1,2 *}$, Eko Setiawan ${ }^{1,2}$ \\ ${ }^{I}$ Pusat Informasi Obat dan Layanan Kefarmasian (PIOLK), Fakultas Farmasi, Universitas Surabaya, Surabaya \\ ${ }^{2}$ Departemen Farmasi Klinis dan Komunitas, Fakultas Farmasi, Universitas Surabaya, Surabaya. \\ E-mail: stevenvictoria@staff.ubaya.ac.id
}

Article Info:

Received: 13 Februari 2020

in revised form: 16 Februari 2020

Accepted: 17 Maret 2020

Available Online: 17 Maret 2020

Keywords:

Ceftaroline

Cephalosporins

Methicillin-resistant

Staphylococcus aureus

Corresponding Author:

Steven Victoria Halim

Fakultas Farmasi

Universitas Surabaya

Surabaya

60284

Indonesia

email :

stevenvictoria@staff.ubaya.ac.id

\begin{abstract}
A growing problem in the medical field is the development of antibiotic resistant pathogens. One reason this development is so important is that in recent years there is a shortage of new antibiotics in development to combat resistant pathogens. It worths to mention that while 19 new antibiotics were released in the period 1980 to 1984 , this had dropped to just three in the period 2005 to 2009. Ironically, the shortage of new antibiotics occur in the era where growing number of pathogens develop resistance to multiple antibiotics that previously effectively used to treat the infections. As a consequent, it is essential that the efficacy of last resort antibiotics, including the new antibiotics, be maintained as long as possible. Ceftaroline is a new antibiotic in Indonesia market which has methicillin-resistant Staphylococcus aureus activity and it belongs to the cephalosporins. Further understanding related to basic profile of ceftaroline, efficacy and safety, cost, and place in therapy is needed to optimize the responsible used of ceftaroline in daily medical practice
\end{abstract}

(C) (9)
Copyright $\odot$ 2019 JFG-UNTAD
This open access article is distributed under a Creative Commons Attribution (CC-BY-NC-SA) 4.0 International license.

How to cite (APA $6^{\text {th }}$ Style):

Halim, S.V., \& Setiawan, E. (2020). Seftarolin, Antibiotik Baru dengan Aktivitas Anti-MRSA: Sebuah Kajian Efektivitas, Keamanan, dan Biaya Penggunaan. Jurnal Farmasi Galenika: Galenika Journal of Pharmacy (e-Journal), 6(1), 160-180. doi:10.22487/j24428744.2020.v6.i1.15015 


\section{ABSTRAK}

Peningkatan jumlah patogen yang mengalami resistensi terhadap antibiotik merupakan permasalahan di bidang kesehatan. Salah satu faktor yang menyebabkan infeksi akibat patogen resisten menjadi permasalahan besar adalah kelangkaan antibiotik baru untuk mengatasi patogen resisten. Sebagai catatan penting, jumlah temuan antibiotik baru turun dari 19 jenis selama kurun waktu 1980-1984 menjadi tiga jenis selama periode waktu 20052009. Sayangnya, kelangkaan antibiotik baru tersebut terjadi pada suatu masa dimana terjadi peningkatan jumlah patogen yang mengalami resistensi terhadap lebih dari satu jenis antibiotik yang sebelumnya efektif untuk mengatasi infeksi. Oleh karena itu, efektivitas dari antibiotik lini akhir, termasuk antibiotik baru, seharusnya dijaga selama mungkin. Seftarolin merupakan sebuah antibiotik baru di Indonesia dari golongan sefalosporin yang memiliki aktivitas terhadap MRSA. Pemahaman mendalam terkait profil dasar seftarolin, bukti efektivitas dan keamanan, biaya terapi, serta posisi seftarolin dalam terapi dibutuhkan untuk mengoptimalkan penggunaan seftarolin secara bertanggung jawab.

Kata kunci: Seftarolin, Sefalosporin, Methicillin-resistant Staphylococcus aureus.

\section{PENDAHULUAN}

Penyakit infeksi merupakan salah satu permasalahan yang menyebabkan peningkatan beban, baik secara klinis maupun finansial, suatu sistem kesehatan secara global (GBD 2015 and HALE Collborators, 2016; Traebert et al., 2016; Van Lier et al., 2016). Dibandingkan dengan data satu dekade yang lalu, angka disability-adjusted life year (DALY) yang disebabkan oleh infeksi pada 195 negara di dunia cenderung mengalami penurunan (GBD 2015 and HALE Collborators, 2016). Disability-adjusted life year (DALY) merupakan salah satu parameter yang direkomendasikan untuk mengukur beban suatu penyakit sehingga dapat dilakukan perbandingan beban antar waktu, antar golongan penyakit, dan antar negara (Devleesschauwer et al., 2014). Penemuan antibiotik baru dengan spektrum aktivitas antibakteri yang lebih baik hingga akhir dekade tahun 2000-an merupakan salah satu faktor penting yang berkontribusi terhadap penurunan DALY tersebut (Centers for Disease Control, 2013; Lobanovska \& Pilla, 2017). Ironisnya, keberhasilan penggunaan antibiotik untuk menurunkan DALY akibat penyakit infeksi dapat mengalami penurunan yang bermakna (Kmietowicz, 2017). Faktor utama penyebab ancaman tersebut adalah peningkatan kasus infeksi oleh patogen yang mengalami resistensi terhadap satu atau lebih jenis antibiotik dan kelangkaan antibiotik baru untuk mnegatasi infeksi akibat patogen tersebut. Tanpa adanya intervensi yang tepat, pada tahun 2050, angka kematian yang disebabkan oleh infeksi dapat lebih tinggi dibandingkan dengan kematian akibat kanker (O’Neill, 2014).

Salah satu jenis patogen yang sering teridentifikasi sebagai penyebab infeksi dan mengalami peningkatan temuan kasus resistensinya adalah Staphylococcus aureus (Chen \& Huang, 2014; Ding et al., 2009; Doyle et al., 2011; Tsering et al., 2011; Vincent et al., 2009). Penelitian yang dilakukan pada sebuah rumah sakit (single site) menunjukkan S. aureus sebagai patogen penyebab infeksi darah (Blood Stream Infection; BSI) dan infeksi saluran nafas bagian bawah (Lower Respiratory Tract Infection; LRTI) nomor 3 dan 4 terbanyak, secara berturut-turut (Ding et al., 2009). Hasil penelitian pada sebuah rumah sakit tersebut selaras dengan hasil temuan multi-site research yang semakin mempertegas besarnya beban penyakit infeksi yang disebabkan oleh S. aureus. Vincent et al., (2009) menemukan S. aureus sebagai patogen gram positif terbanyak di ruang rawat intensif (intensive care unit; ICU) rumah sakit di kawasan Eropa Barat, Eropa Timur, Amerika Tengah/Selatan, Amerika Utara, Oseania, Afrika, dan Asia (Vincent et al., 2009). Ironisnya, beberapa bukti penelitian menunjukkan persentase dari S. aureus yang mengalami resistensi menjadi methicillin-resistant Staphylococcus aureus (MRSA) dapat dikatakan cukup besar (Doyle et al., 2011; Tsering et al., 2011; Vincent et al., 2009). Doyle et al., (2011) melaporkan sebanyak 56,80\%, 65,20\%, dan 54,40\% dari total S. aureus yang teridentifikasi pada kasus central line associated BSI, cathether associated urinary tract infection (UTI), dan ventilator-associated pneumonia (VAP) telah membentuk mekanisme resistensi terhadap metisilin (Doyle et al., 2011). Penelitian di kawasan Asia menunjukkan rentang prevalensi infeksi yang disebabkan oleh MRSA berkisar antara 0\%-87,4\%. Di Indonesia, 
terdapat sebuah penelitian terpublikasi yang menyatakan persentase temuan MRSA pada sebuah rumah sakit sebesar 28\% (Chen \& Huang, 2014).

Vankomisin merupakan antibiotik pilihan pertama untuk infeksi yang disebabkan oleh MRSA (Liu et al., 2011). Namun demikian, akhir-akhir ini efektivitas vankomisin untuk terapi infeksi oleh MRSA semakin dipertanyakan dengan mempertimbangkan temuan strain MRSA dengan peningkatan nilai minimum inhibitory concentration (MIC) vankomisin (van Hal et al., 2012; Wi et al., 2012; Yeh et al., 2012). Saat ini terdapat beberapa antibiotik di Indonesia yang dapat digunakan sebagai terapi untuk kasus infeksi oleh MRSA yang tidak dapat teratasi oleh vankomisin, antara lain: linesolid dan daptomisin (Canut et al., 2012; Moore et al., 2011). Namun demikian, antibiotik tersebut tidak dapat digunakan untuk seluruh kasus infeksi akibat MRSA, misalnya: daptomisin yang tidak efektif untuk kasus infeksi MRSA dengan site of infection di paru-paru (Sauermann et al., 2008; Silverman et al., 2005). Oleh karena itu, keberadaan antibiotik dengan aktivitas anti-MRSA lain dibutuhkan sebagai alternatif terapi untuk kasus yang tidak dapat teratasi oleh beberapa antibiotik yang saat ini terdapat di Indonesia.

Seftarolin, sebuah antibotik sefalosporin generasi ke-5, merupakan antibiotik lain yang dapat berperan penting dalam tata laksana penyakit infeksi oleh MRSA (Beauduy \& Winston, 2018; Craig \& Andes, 2015; Gallagher \& MacDougall, 2018; Tortora et al., 2019). Tinjuan pustaka ini bertujuan untuk mengkaji literatur terkait profil dasar seftarolin, bukti efektivitas dan keamanan, biaya terapi, serta posisi seftarolin dalam terapi. Profil dasar yang dibahas pada tinjauan pustaka ini meliputi: mekanisme kerja, struktur kimia, parameter farmakokinetika-farmakodinamika (atau disebut juga dengan istilah farmakokinetika-farmakodinamika indeks), dan indikasi yang disetujui oleh lembaga yang memiliki otoritas (approved indication). Konsep umum terkait prinsip farmakokinetika-farmakodinamika pada terapi infeksi akan dipaparkan terlebih dahulu sebagai pengantar sebelum pembahasan secara lebih spesifik untuk seftarolin. Hanya artikel penelitian dalam bentuk kajian sistematis dan meta-analisis pada kasus infeksi sesuai dengan approved indication yang ditampilkan pada bagian efektivitas dan keamanan seftarolin. Dasar pemilihan jenis artikel tersebut mengacu pada hierarki bukti penelitian (level of evidence), dimana kedua jenis artikel tersebut ditempatkan pada tingkat tertinggi. Sebagai upaya untuk memetakan posisi seftarolin dalam tata laksana penyakit infeksi, beberapa pedoman terapi sesuai dengan approved indication akan digunakan pada tinjauan pustaka ini. Selain seftarolin, masih terdapat antibiotik lain dari golongan sefalosporin generasi ke-5 yang memiliki aktivitas terhadap MRSA, yakni: seftobiprol. Namun demikian, informasi terkait seftobiprol tidak termasuk dalam tinjauan pustaka ini.

\section{MEKANISME KERJA, STRUKTUR KIMIA, DAN INDIKASI PADA LABEL}

Seftarolin dapat mengeradikasi bakteri dengan cara berikatan pada penicillin binding protein (PBP) 1a, 1b, 2a, 2b, 2x, dan 3 yang menyebabkan proses pembentukan jembatan (cross-linking) antar komponen penyusun dinding sel bakteri tidak terjadi. Aktivitas seftarolin terhadap MRSA terjadi melalui ikatan terhadap PBP 2a. Apabila dibandingkan dengan antibiotik lain dari golongan betalaktam, seftarolin memiliki afinitas yang lebih tinggi terhadap PBP 2a. Aktivitas pada PBP 2a inilah yang menjadi target resistensi MRSA terhadap Seftarolin, yaitu dengan mengubah gen MecA yang berperan penting pada pembentukan PBP 2a (Craig \& Andes, 2015; Gallagher \& MacDougall, 2018; Zhanel et al., 2009). Selain afinitas terhadap PBP 2a yang tinggi, aktivitas seftarolin terhadap MRSA juga terkait dengan keberadaan cincin 1,3 thiazole dan oxime group pada strukturnya (Gambar 1). Beberapa kelebihan lain dari struktur kimia seftarolin antara lain:

a. keberadaan cincin 1,2,4 thiadiazole yang dapat meningkatkan afinitas terhadap enzim transpeptidase, salah satunya PBP, dan meningkatkan permeabilitas terhadap bakteri gram negatif,

b. keberadaan grup fosfono yang dapat meningkatkan kelarutan seftarolin dalam air, namun grup fosfono ini hanya terdapat pada saat seftarolin berada dalam bentuk prodrug (Zhanel et al., 2009). 


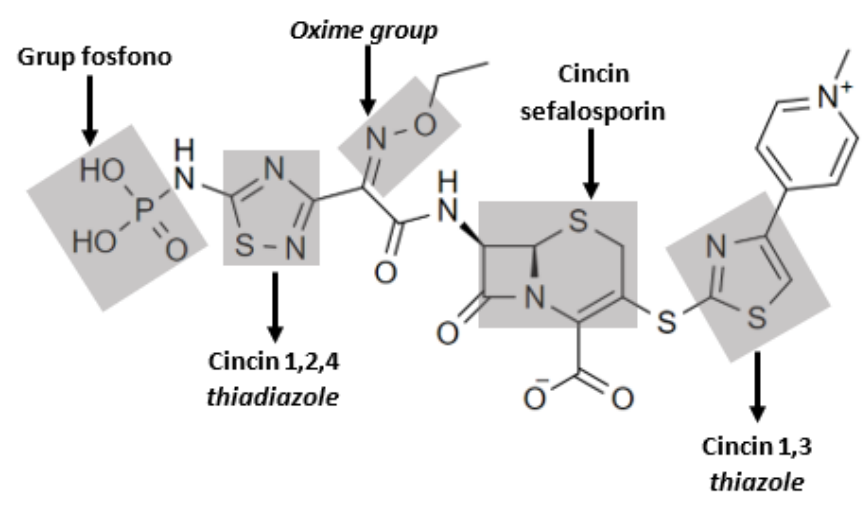

Gambar 1. Struktur Seftarolin

Seftarolin yang tersedia di pasaran adalah seftarolin fosamil yang merupakan prodrug. Dalam tubuh manusia, seftarolin fosamil akan segera dimetabolisme oleh enzim fosfatase di plasma menjadi bentuk aktif, yakni: seftarolin. Metabolisme seftarolin tidak melibatkan enzim sitokrom P450 (CYP P450) melainkan proses hidrolisis pada cincin beta laktam menjadi metabolit tidak aktif, yaitu seftarolin M1. Detail profil farmakokinetika seftarolin mulai dari absorpsi sampai dengan ekskresi dapat dilihat pada tabel 1 (American society of health-system pharmacist, 2018; Craig \& Andes, 2015).

Tabel 1. Farmakokinetika Seftarolin

\begin{tabular}{|c|c|}
\hline $\begin{array}{l}\text { Farmako- } \\
\text { kinetika }\end{array}$ & Keterangan \\
\hline Absorpsi & $\begin{array}{l}\mathrm{C}_{\max } \text { dan } \mathrm{t}_{\max } \\
\text { 1. Seftarolin } 600 \mathrm{mg} \text { diberikan secara IV infus selama } 60 \text { menit setiap } 12 \text { jam } \\
\text { dalam } 14 \text { hari menunjukkan } \mathrm{C}_{\max } 21,3 \mu \mathrm{g} / \mathrm{ml} \text { dan } \mathrm{t}_{\max } 0,9 \text { jam } \\
\text { 2. Seftarolin } 600 \mathrm{mg} \text { diberikan secara } \mathrm{IV}(50 \mathrm{ml}) \text { selama } 5 \text { menit setiap } 8 \text { jam } \\
\text { menunjukkan } \mathrm{C}_{\max } 32,5 \mu \mathrm{g} / \mathrm{ml} \\
\text { 3. Seftarolin } 600 \mathrm{mg} \text { diberikan secara } \mathrm{IV}(50 \mathrm{ml}) \text { selama } 60 \text { menit setiap } 8 \text { jam } \\
\text { dalam } 5 \text { hari menunjukkan } \mathrm{C}_{\max } 17,4 \mu \mathrm{g} / \mathrm{ml}\end{array}$ \\
\hline Distribusi & $\begin{array}{l}\text { 1. } \mathrm{V}_{\mathrm{d}} \text { pada pasien dewasa sehat saat masa tunak adalah } 20,3 \mathrm{~L} \\
\text { 2. Ikatan obat protein } 20 \%\end{array}$ \\
\hline Metabolisme & $\begin{array}{l}\text { Seftarolin fosamil adalah prodrug yang akan dimetabolisme enzim fosfatase di } \\
\text { plasma menjadi bentuk aktif seftarolin. Seftarolin dimetabolisme lebih lanjut } \\
\text { melalui proses hidrolisis menjadi bentuk tidak aktif Seftarolin M-1 }\end{array}$ \\
\hline Ekskresi & $\begin{array}{l}\text { Seftarolin dan metabolitnya diekskresi melalui urin setelah melewati filtrasi } \\
\text { glomerulus ( } 64 \% \text { sebagai bentuk tidak berubah, dan } 2 \% \text { bentuk metabolit } \\
\text { Seftarolin M-1) dan } 6 \% \text { diekskresi melalui feses } \\
\text { Waktu paruh eliminasi adalah } 2,7 \text { jam }\end{array}$ \\
\hline
\end{tabular}

Keterangan Tabel 1: $\mathrm{V}_{\mathrm{d}}=$ volume distribusi, $\mathrm{IV}=$ intravena

Seftarolin fosamil mendapatkan ijin edar di Amerika Serikat dari Food and Drug Administration (FDA) pada tahun 2010 dengan nama dagang Teflaro ${ }^{\circledR}$ (Food and Drug Administration, 2012). Beberapa tahun kemudian, seftarolin fosamil memperoleh ijin edar di Eropa (oleh European Medicine Agency; EMA tahun 2012) dan Australia (oleh Therapeutics Goods Administration; TGA tahun 2013) dengan nama dagang yang berbeda, yaitu Zinforo ${ }^{\circledR}$ (European Medicines Agency, 2019; Therapeutic Goods Administration Health Safety Regulation, 2013). Selain nama dagang yang berbeda, seftarolin yang tersedia di Amerika Serikat berbeda dengan yang tersedia di Eropa dan Australia dari segi kekuatan sediaan. Teflaro ${ }^{\circledR}$ memiliki 2 (dua) kekuatan, yaitu: $400 \mathrm{mg}$ dan $600 \mathrm{mg}$ serbuk steril dalam $20 \mathrm{ml}$ vial, sedangkan Zinforo ${ }^{\circledR}$ hanya memiliki 1 kekuatan sediaan, yaitu $600 \mathrm{mg}$ dengan bentuk 
sediaan yang sama. Indikasi penggunaan seftarolin yang disetujui di tiga negara tersebut (approved indication), yaitu: acute bacterial skin and skin structure infections (ABSSSi)/skin and soft tissue infection (SSTi) dan community-acquired bacterial pneumonia (CABP). Aturan penggunaan untuk pasien dewasa yang disetujui di tiga negara tersebut adalah sebagai berikut:

a. untuk indikasi CABP, ABSSi atau SSTi dapat menggunakan Seftarolin dengan dosis $600 \mathrm{mg}$ setiap 12 jam yang diberikan secara infus selama 1 jam.

b. untuk indikasi CABP dan ABSSi/SSTi durasi penggunaannya adalah 5-7 hari dan 5-14 hari, secara berturut-turut.

FARMAKOKINETIKA-FARMAKODINAMIK INDEKS DARI SEFTAROLIN (PHARMACOKINETICS/PHARMACODYNAMICS; PK-PD)

PK-PD indeks merupakan sebuah parameter yang mengintegrasikan aspek farmakokinetik antibiotik dalam tubuh pasien dan aspek farmakodinamik antibiotik terhadap patogen penginfeksi (Kuti, 2016; Onufrak et al., 2016). Aspek farmakokinetik menggambarkan perjalanan antibiotik di dalam tubuh meliputi absorpsi, distribusi, metabolisme, dan ekskresi (ADME). Proses ADME tersebut dapat berbeda antar individu dan menentukan total paparan antibiotik dalam tubuh pasien. Paparan antibiotik dapat digambarkan sebagai konsentrasi per-satuan waktu atau sebagai suatu area di bawah suatu gambaran kurva (area under the curve; AUC). Beberapa nilai konsentrasi pada waktu yang berbeda diperlukan untuk dapat menggambarkan AUC (Rowland \& Tozer, 2011). Efek antibiotik terhadap patogen penginfeksi digambarkan dengan nilai minimum inhibitory concentration (MIC), yaitu konsentrasi terkecil dari antibiotik yang dapat menghambat pertumbuhan bakteri (Jorgensen \& Ferraro, 2009). Nilai integrasi data farmakokinetik dan data farmakodinamik suatu antibiotik dapat memiliki keterkaitan dengan keberhasilan terapi, baik secara klinis maupun mikrobiologis. Oleh karena itu, nilai PK-PD indeks, dewasa ini, digunakan sebagai target untuk menentukan dosis dan frekuensi pemberian antibiotik yang paling optimal untuk setiap individu pasien. Gambar 2 dapat digunakan sebagai ilustrasi PK-PD indeks.

Beberapa hal yang perlu diperhatikan dalam mengimplementasikan prinsip PK-PD antibiotik, antara lain (Kuti, 2016; Onufrak et al., 2016; Roberts et al., 2014; Setiawan et al., 2019):

1. PK-PD indeks ditentukan oleh aktivitas eradikasi bakteri (bacterial killing activities) yang dibedakan menjadi: concentration- dan time-dependent bacterial killing,

2. PK-PD indeks untuk suatu jenis antibiotik dapat lebih dari satu,

3. nilai target PK-PD indeks dapat berbeda untuk beberapa jenis antibiotik dalam satu golongan,

4. nilai target PK-PD indeks dapat berbeda untuk suatu jenis antibiotik terhadap bakteri yang berbeda,

5. nilai target PK-PD indeks dapat berbeda untuk jenis antibiotik yang berbeda terhadap suatu bakteri spesifik,

6. nilai PK-PD untuk suatu antibiotik terhadap suatu bakteri spesifik dapat berbeda pada uji dengan desain yang berbeda, khususnya uji pre-klinis (in-vitro dan in-vivo) dan uji klinis.

Perlu diketahui bahwa nilai PK-PD target yang dihasilkan dari penelitian uji klinis, umumnya, digunakan sebagai pilihan pertama pada saat melakukan penelitian terkait simulasi dosis antibiotik. Namun demikian, nilai PK-PD dari uji klinis tidak selalu dapat ditemukan pada literatur terpublikasi. 


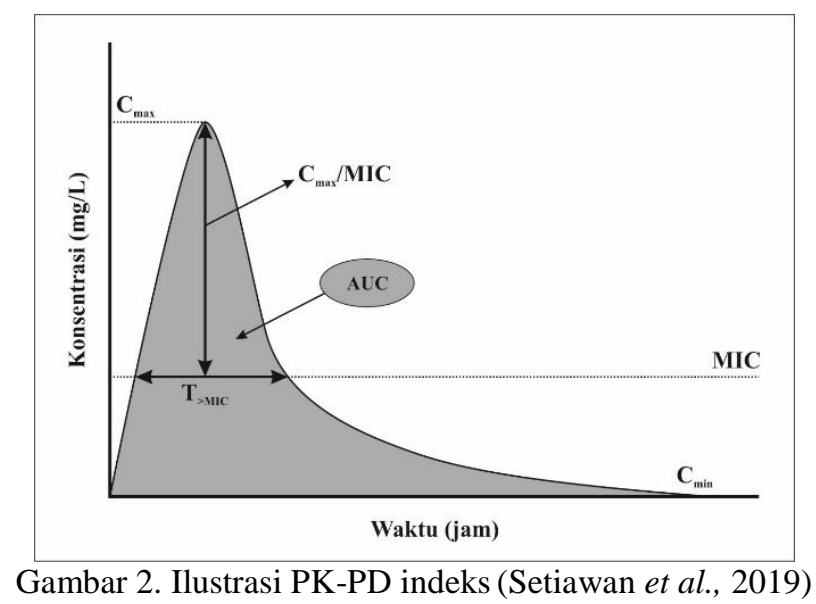

Keterangan gambar 2:

$\mathrm{C}_{\max } \quad:$ Konsentrasi maksimum

$\mathrm{C}_{\min } \quad:$ Konsentrasi minimum

AUC : Area under the curve

$\mathrm{C}_{\max } / \mathrm{MIC} \quad$ : Rasio antara konsentrasi antibiotik maksimum dibandingkan dengan nilai MIC

$\mathrm{AUC}_{0-24} / \mathrm{MIC} \quad$ : Rasio antara area dibawah kurva konsentrasi antibiotik persatuan waktu selama interval waktu tertentu dibandingkan dengan nilai MIC

$\% \mathrm{~T}_{>\mathrm{MIC}} \quad$ : Persentase waktu dalam suatu interval dosis pemberian dimana konsentrasi antibiotik berada di atas nilai MIC

Sebagai antibiotik yang bersifat time-dependent, PK-PD indeks yang berkaitan dengan keberhasilan terapi seftarolin adalah \% $\mathrm{fT}_{>_{\mathrm{MIC}}}$ (Bhavnani et al., 2013; Das et al., 2019; Li et al., 2019). Huruf "f" mengindikasikan nilai PK-PD indeks ditentukan dengan mempertimbang-kan pengukuran kadar seftarolin bebas (atau tidak terikat) saja. Berdasarkan uji pre-klinis, nilai $\% \mathrm{fT}_{>_{\text {MIC }}}$ seftarolin untuk menghasilkan efek statis, $1 \log _{10} \mathrm{kill}, 2 \log _{10}$ kill terhadap S. aureus adalah $27 \%, 31 \%$, dan $35 \%$, secara berturut-turut (Das et al., 2019; Li et al., 2019). Target nilai PK-PD seftarolin untuk menghasilkan efek serupa terhadap beberapa bakteri yang lain dapat dilihat pada tabel 2 (Li et al., 2019). Penelitian uji klinis menunjukkan nilai target $\% \mathrm{fT}_{>\mathrm{MIC}}$ seftarolin yang berbeda dengan hasil uji pre-klinis. Penelitian oleh Bhavnani et al., (2013) pada pasien dengan community-acquired pneumonia (CAP) menunjukkan sebanyak $98,4 \%$ pasien dengan keberhasilan terapi memiliki nilai $\% \mathrm{fT}_{>_{\mathrm{MIC}}}$ sebesar $\geq 63,3$. Namun demikian, dengan mempertimbangkan keterbatasan jumlah sampel pasien, khususnya kasus kegagalan terapi, Bhavnani et al., (2013) tidak melakukan uji analisis univariate sehingga penelitian tersebut belum dapat menyimpulkan nilai 63,3 sebagai threshold atau cut-off point untuk keberhasilan terapi secara klinis (Bhavnani et al., 2013). Oleh karena itu, penelitian dengan jumlah sampel yang lebih besar dibutuhkan untuk memperoleh nilai target PK-PD yang dapat digunakan sebagai threshold atau cut-off point keberhasilan terapi seftarolin.

Tabel 2. Target PK-PD Indeks Seftarolin untuk Beberapa Bakteri (Hasil Penelitian In-Vitro)

\begin{tabular}{lccc}
\hline \multirow{2}{*}{ Bakteri } & \multicolumn{3}{c}{ Nilai $\% \mathbf{f T}_{>\text {MIC }}$ untuk menghasilkan efek } \\
\cline { 2 - 4 } & Statis & $\mathbf{1}_{\log _{\mathbf{1 0}} \text { kill }}$ & $\mathbf{2} \log _{\mathbf{1 0}}$ kill \\
\hline Streptococcus pneumoniae & $35 \%$ & $44 \%$ & $51 \%$ \\
\hline Enterobacteriaceae & $48,5 \%$ & $73 \%$ & $\mathrm{NI}$ \\
\hline
\end{tabular}

Keterangan Tabel 2: NI: No Information

Informasi terkait nilai PK-PD indeks dapat digunakan lebih lanjut untuk menentukan dosis dan frekuensi pemberian seftarolin yang paling tepat untuk kelompok pasien tertentu. Perlu diketahui bahwa dosis sebagian besar obat, termasuk seftarolin, dibuat dengan memperhitungkan profil 
farmakokinetik kelompok dewasa sehat atau pasien dengan kondisi yang relatif stabil pada ras Kaukasian (Caucasian). Oleh karena itu, pemberian seftarolin pada kelompok non-Caucasian, termasuk pada pasien Indonesia, dengan dosis sebagaimana yang tertera pada leaflet tidak dapat diasumsikan akan selalu menghasilkan paparan obat yang setara ketika dosis tersebut diberikan pada kelompok Caucasian. Penentuan profil farmakokinetik seftarolin pada pasien Indonesia, khususnya pada kelompok pasien dengan perubahan kondisi klinis yang sangat dinamis (contoh: pasien kritis di ruang rawat intensif), perlu diupayakan sebagai langkah awal optimalisasi terapi seftarolin di Indonesia. Hasil dari identifikasi profil farmakokinetik tersebut perlu dilanjutkan dengan penentuan dosis optimal seftarolin yang dapat mencapai target nilai PK-PD indeks. Simulasi dengan menggunakan program komputer dapat digunakan sebagai metode untuk menentukan dosis rejimen obat, termasuk seftarolin. Metode simulasi makin banyak digunakan sebagai upaya untuk mengatasi permasalahan dari penelitian klinis yang dilakukan pada manusia secara langsung, misalnya: kebutuhan akan dana yang besar dan waktu yang lama (Dong et al., 2012; Roberts et al., 2011). Simulasi komputer merupakan suatu teknik yang menggunakan prinsip matematika dan didesain sedemikian rupa sehingga dapat menyerupai proses yang terjadi pada dunia nyata. Markov dan Monte Carlo model merupakan dua tipe program simulasi yang sering digunakan pada penelitian biomedis (Dong et al., 2012).

\section{PLACE ON THERAPY}

Hasil kajian pada beberapa panduan terapi menunjukkan bahwa seftarolin tidak selalu direkomendasikan sebagai terapi lini pertama pengobatan pada pasien dengan CABP dan ABSSSi/SSTi (Chou et al., 2019; Golan, 2019; Metlay et al., 2019; National Institute for Health and Care Excellence, 2019). Pada kasus CABP, panduan terapi National Institute for Health and Care Excellence (NICE) tahun 2019 belum merekomendasikan penggunaan seftarolin sebagai pilihan terapi pada pasien pneumonia, baik community acquired pneumonia (CAP), hospital acquired pneumonia (HAP), maupun ventilator associated pneumonia (VAP). Tidak demikian halnya dengan panduan terapi yang dikeluarkan oleh Infectious Diseases Society of America (IDSA) tahun 2019 yang merekomendasikan penggunaan kombinasi antara antibiotik golongan beta laktam, dan salah satu jenis yang jelas direkomendasikan adalah seftarolin, dengan golongan makrolida sebagai rejimen standar untuk pasien dengan CAP (Metlay et al., 2019). Panduan terapi lain yang dikeluarkan oleh salah satu negara di kawasan Asia, yakni Taiwan, memberikan rekomendasi yang sejalan dengan rekomendasi dari IDSA (Chou et al., 2019). Hanya saja, pada panduan terapi dari negara Taiwan dinyatakan bahwa seftarolin diutamakan sebagai terapi alternatif untuk pasien CAP dengan tingkat keparahan sedang (indeks keparahan pneumonia; CURB 2-3). Pada kasus ABSSSi/SSTI, seftarolin direkomendasikan oleh panduan terapi IDSA, secara khusus ABSSSi/SSTi yang diduga disebabkan oleh MRSA (Golan, 2019).

Perbedaan posisi terapi pada berbagai pedoman terapi mengindikasikan bahwa penggunaan seftarolin tidak selalu harus ditempatkan sebagai pilihan terapi pertama. Beberapa hal berikut dapat digunakan sebagai dasar pertimbangan untuk menggunakan seftarolin, antara lain: 1) prevalensi kejadian infeksi yang disebabkan oleh MRSA khususnya yang mengalami penurunan sensitivitas terhadap vankomisin atau mengalami resistensi, 2) risiko terjadinya reaksi obat yang tidak dikehendaki (ROTD), sebagai contoh pada pasien dengan dosis vankomisin yang tinggi. Penurunan sensitivitas vankomisin ditandai dengan peningkatan nilai MIC dari strain MRSA walaupun masih diklasifikasikan sebagai strain yang sensitif terhadap vankomisin, atau dikenal juga sebagai fenomena "MIC Creep". European Committee on Antimicrobial Susceptibility Testing (EUCAST) menyatakan batas atas untuk mengklasifikasikan MRSA sensitif terhadap vankomisin adalah $\leq 2 \mathrm{mg} / \mathrm{L}$ (European Committee on Antimicrobial Susceptibility Testing, n.d.). Sebuah kajian terpublikasi menunjukkan bahwa dosis standar vankomisin, yakni 1 gram setiap 12 jam, tidak cukup efektif untuk terapi infeksi yang disebabkan strain MRSA dengan MIC > 1,5 mg/L (Setiawan \& Montakantikul, 2018). Ironisnya, fenomena peningkatan nilai MIC MRSA terhadap vankomisin ditemukan pada banyak literatur terpublikasi (Pitz 
et al., 2011; Yeh et al., 2012). Sebuah penelitian dengan menggunakan Monte Carlo Simulasi pada pasien kritis di Thailand menunjukkan dosis vankomisin sampai dengan $3 \mathrm{~g} / \mathrm{hari}$ dan $4 \mathrm{~g} / \mathrm{hari}$ dibutuhkan untuk mengatasi infeksi oleh MRSA dengan MIC 1,5 mg/L dan $2 \mathrm{~g} / \mathrm{L}$, secara berturutturut. Peningkatan dosis tersebut diikuti dengan peningkatan risiko terjadinya nephrotoxicity. Risiko nephrotoxicity pada dosis 2 g/hari, 3 g/hari, dan 4 g/hari adalah 18,27\%, 26,59-28,02\%, dan 31,20$32,96 \%$, secara berturut-turut (Setiawan et al., 2019). Selain peningkatan dosis, beberapa faktor lain yang dapat menyebabkan nephrotoxicity pada pasien yang mendapatkan vankomisin, antara lain: mendapat perawatan di intensive care unit (ICU), memiliki nilai serum kreatinin yang tinggi, penggunaan bersamaan dengan obat lain yang dapat menyebabkan nephrotoxicity (khususnya aminoglikosida), dan penggunaan vankomisin dalam jangka waktu lama (Cano et al., 2012; Kullar et al., 2011; Minejima et al., 2011; Pritchard et al., 2010; Spapen et al., 2011; Wong-Beringer et al., 2011). Oleh karena itu, penggunaan seftarolin dapat dipertimbangkan pada pasien dengan beberapa kriteria berikut:

a. Pasien terinfeksi MRSA dan dirawat di rumah sakit dengan prevalensi tinggi terkait temuan MRSA resisten terhadap vankomisin atau "MIC Creep"

b. Pasien memiliki faktor risiko tinggi mengalami nephrotoxicity akibat penggunaan vankomisin atau antibiotik alternatif yang lain.

Upaya untuk mengawal penggunaan seftarolin yang bertanggung jawab perlu dioptimalkan dengan mempertimbangkan beberapa hal. Pertama, sebagai antibiotik baru, seftarolin perlu ditempatkan sebagai antibiotik last resort atau "senjata terakhir" untuk kasus infeksi yang tidak dapat teratasi oleh antibiotik lain dan untuk pasien yang terinfeksi bakteri multiple drug resistant (MDR). Penggunaan yang terlalu sering untuk kasus infeksi yang seharusnya tidak membutuhkan seftarolin akan memicu resistensi. Oleh karena itu, sebagaimana juga dinyatakan oleh World Health Organization (WHO) dalam program AWaRe (Access, Watch, Reserve), seftarolin seharusnya dimasukkan dalam kategori antibiotik yang direstriksi penggunaannya (World Health Organization, 2019). Kedua, penggunaan seftarolin pada kasus CABP dan ABSSSi/SSTi tidak selalu lebih efektif dibandingkan dengan antibiotik lain. Pada bagian efektivitas seftarolin untuk CABP dan ABSSSi/SSTi akan dipaparkan lebih terperinci terkait bukti penelitian yang membandingkan seftarolin dan antibiotik lain. Ketiga, biaya penggunaan seftarolin lebih mahal dibandingkan dengan antibiotik lain. Pada bagian biaya penggunaan akan dipaparkan total biaya per-hari dan per-siklus pengobatan pada kasus CABP dan ABSSi/SSTi.

\section{EFEKTIVITAS SEFTAROLIN UNTUK CABP DAN ABSSSi/SSTi}

Penting untuk disampaikan bahwa bakteri penyebab CABP dan ABSSSi/SSTi tidak hanya S. aureus atau MRSA saja. Oleh karena itu, antibiotik pembanding yang digunakan pada penelitian uji efektivitas secara klinis tidak selalu harus memiliki aktivitas terhadap S. aureus atau MRSA. Pemilihan antibiotik pembanding dapat didasarkan pada beberapa kriteria dan salah satu kriteria yang terpenting adalah antibiotik pembanding merupakan salah satu antibiotik terbaik untuk indikasi tersebut.

Pada kasus pneumonia, sebagian besar antibiotik pembanding yang digunakan dalam penelitianpenelitian yang dilibatkan pada kajian sistematis dan meta-analisis adalah seftriakson (Chen et al., 2019; Hajj et al., 2017; Lan et al., 2019; Sotgiu et al., 2018). Sebuah meta-analisis pada kasus pneumonia melibatkan bukti penelitian yang menggunakan pembanding vankomisin baik dengan maupun tanpa linezolid (World Health Organization, 2019). Hasil analisis terhadap kajian sistematis dan meta-analisis menyatakan bahwa seftarolin memiliki efektivitas yang lebih baik dibandingkan dengan antibiotik pembanding pada beberapa outcome klinis. Namun demikian, pada beberapa subgrup analisis, efektivitas seftarolin tidak berbeda secara bermakna dibandingkan dengan antibiotik pembanding (Lan et al., 2019). Detail hasil dari kajian sistematik dan meta-analisis mengenai efektivitas seftarolin pada pasien CABP dapat dilihat pada tabel 3. Sebagai catatan, sampai dengan 
artikel ini ditulis, kajian sistematis dan meta-analisis terpublikasi terkait efektivitas seftarolin pada kasus CABP dibandingkan dengan antibiotik lain yang memiliki aktivitas anti MRSA lain seperti linesolid belum ditemukan.

Pada kasus ABSSSi/SSTi, antibiotik pembanding yang digunakan adalah vankomisin baik sebagai terapi tunggal maupun kombinasi dengan aztreonam, metronidasol, atau ampisilin-sulbaktam (Chihwei Chen et al., 2019; Hajj et al., 2017; Lan, Chang, Lai, \& Lu, 2019). Sefazolin juga ditemukan sebagai antibiotik pembanding pada sebuah kajian sistematis dan meta-analisis (Chih-wei Chen et al., 2019). Secara umum, hasil dari beberapa kajian sistematis dan meta-analisis pada kasus ABSSSi/SSTi menunjukkan bahwa efektivitas seftarolin tidak berbeda secara signifikan dibandingkan dengan antibiotik pembanding. Detail hasil dari kajian sistematik dan meta-analisis mengenai efektivitas seftarolin pada pasien CABP dapat dilihat pada tabel 3.

Tabel 3. Ringkasan Kajian Sistematik Terkait Efektivitas Seftarolin pada Pasien CABP dan ABSSSi/ SSTi

\begin{tabular}{|c|c|c|c|c|}
\hline $\begin{array}{l}\text { Pengarang } \\
\text { (tahun) }\end{array}$ & $\begin{array}{c}\text { Jumlah } \\
\text { penelitian }\end{array}$ & Populasi & Terapi & Luaran penelitian \\
\hline $\begin{array}{l}\text { Sotgiu et al } \\
\quad(2018)\end{array}$ & $\begin{array}{c}14 \\
\text { penelitian* }\end{array}$ & $\begin{array}{l}\text { Pasien } \\
\text { CAP, HAP, } \\
\text { VAP, } \\
\text { HCAP }\end{array}$ & $\begin{array}{l}\text { Seftarolin } v s \\
\text { Seftriakson } \\
\text { (6 artikel) } \\
\text { atau } \\
\text { Vankomisin } \\
\text { dengan } \\
\text { maupun } \\
\text { tanpa } \\
\text { Linezolid (1 } \\
\text { artikel) }\end{array}$ & $\begin{array}{l}\text { 1. Persentase pasien dengan keberhasilan } \\
\text { terapi secara klinis setelah } \\
\text { mendapatkan terapi seftarolin pada } \\
\text { kasus: } \\
\text { a. pneumonia secara keseluruhan, } \\
\text { termasuk pasien CAP, HAP, VAP, } \\
\text { dan HCAP adalah } 81,2 \% \text { (95\% CI } \\
\text { 79,9-82,6\%) } \\
\text { b. CAP adalah 81,3\% (95\% CI 80,0- } \\
\text { 82,7\%) } \\
\text { c. HAP/VAP/HCAP adalah 83,0\% } \\
\text { (95\% CI 65,0-95,0\%) } \\
\text { 2. Hasil pooled analysis pada } 8 \text { studi } \\
\text { yang menyertakan antibiotik } \\
\text { pembanding menunjukkan nilai RR } \\
\text { untuk kesembuhan secara klinis } \\
\text { berpihak pada seftarolin dengan nilai } \\
\text { RR = 1,1 (95\% CI 1,1-1,2; I }{ }^{2}=0,00 \% \text { ) } \\
\text { 3. Analisis berdasarkan patogen } \\
\text { penyebab infeksi menunjukkan bahwa } \\
\text { persentase pasien dengan keberhasilan } \\
\text { terapi secara klinis maupun } \\
\text { mikrobiologis adalah sebagai berikut: } \\
\text { a. Streptococcus pneumoniae: } \\
82,6 \% \text { (95\% CI 78,6-86,4) } \\
\text { b. MDR Streptococcus } \\
\text { pneumoniae: } 93,0 \% \text { (95\% CI } \\
77,0-100,0 \% \text { ) } \\
\text { c. MSSA: } 72,3 \% \text { (95\% CI 64,5- } \\
\text { d9, MRS) } \\
\text { d. } 81,7 \% \text { (95\% CI 59,7- }\end{array}$ \\
\hline $\begin{array}{l}\text { Lan et al } \\
(2019)\end{array}$ & $5 \mathrm{RCT}$ & $\begin{array}{l}3 \mathrm{RCT} \\
\text { pasien }\end{array}$ & $\begin{array}{l}\text { Seftarolin } v s \\
\text { Seftriakson }\end{array}$ & $\begin{array}{l}\text { 1. Tingkat kesembuhan secara klinis } \\
\text { pada kelompok pasien dengan terapi }\end{array}$ \\
\hline
\end{tabular}




\begin{tabular}{|c|c|c|c|c|}
\hline $\begin{array}{c}\text { Pengarang } \\
\text { (tahun) }\end{array}$ & $\begin{array}{c}\text { Jumlah } \\
\text { penelitian }\end{array}$ & Populasi & Terapi & Luaran penelitian \\
\hline & & $\begin{array}{l}\text { CABP } \\
\text { dewasa dan } \\
2 \text { RCT } \\
\text { pasien } \\
\text { CABP } \\
\text { anak-anak }\end{array}$ & & 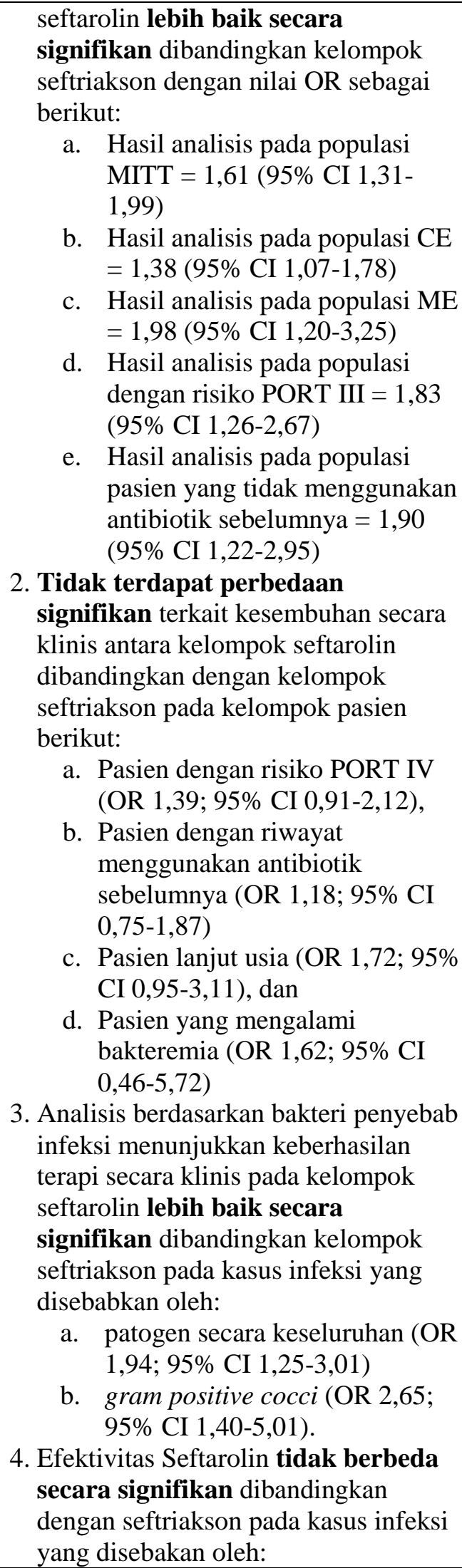 \\
\hline
\end{tabular}




\begin{tabular}{|c|c|c|c|c|}
\hline $\begin{array}{c}\text { Pengarang } \\
\text { (tahun) }\end{array}$ & $\begin{array}{c}\text { Jumlah } \\
\text { penelitian }\end{array}$ & Populasi & Terapi & Luaran penelitian \\
\hline & & & & $\begin{array}{ll}\text { a. } & \text { Streptococcus pneumoniae (OR } \\
& \text { 2,05; 95\% CI 0,99-4,25), } \\
\text { b. Staphylococcus aureus (OR } \\
\text { 2,17; 95\% CI 0,74-6,33), } \\
\text { c. } \text { Bakteri gram negatif (OR 1,26; } \\
\text { 95\% CI 0,65-2,42), } \\
\text { d. Haemophilus influenzae (OR } \\
\text { 1,13; 95\% CI 0,26-4,99), } \\
\text { e. Haemophilus parainfluenzae } \\
\text { (OR 2,44; 95\% CI 0,34-17,60), } \\
\text { f. Escherichia coli (OR 1,76; 95\% } \\
\text { CI 0,36-8,50), dan } \\
\text { g. Klebsiella pneumoniae (OR } \\
\text { 1,94; 95\% CI 0,53-7,16). }\end{array}$ \\
\hline
\end{tabular}

\begin{tabular}{|c|c|c|c|c|}
\hline $\begin{array}{l}\text { Hajj et al } \\
\text { (2016) }\end{array}$ & $3 \mathrm{RCT}$ & $\begin{array}{l}\text { Pasien CAP } \\
\text { dewasa }\end{array}$ & $\begin{array}{l}\text { Seftarolin } v s \\
\text { Seftriakson }\end{array}$ & $\begin{array}{l}\text { 1. Kesembuhan secara klinis pada } \\
\text { kelompok pasien yang memperoleh } \\
\text { seftarolin lebih baik secara } \\
\text { signifikan dibandingkan pasien yang } \\
\text { mendapt seftriakson (RR } 1,12 ; 95 \% \\
\text { CI } 1,07-1,18 \text { ) } \\
\text { 2. Kematian akibat CAP tidak berbeda } \\
\text { secara signifikan antara pasien yang } \\
\text { memperoleh terapi seftarolin } \\
\text { dibandingkan dengan seftriakson (RR } \\
\text { 1,12; 95\% CI } 0,58-2,19)\end{array}$ \\
\hline $\begin{array}{l}\text { Chen et al } \\
\text { (2019) }\end{array}$ & $\begin{array}{c}3 \\
\text { randomized } \\
\text { study }\end{array}$ & $\begin{array}{l}\text { Pasien } \\
\text { pediatrik } \\
\text { CAP (2 } \\
\text { studi) dan } \\
\text { ABSSSi }\end{array}$ & $\begin{array}{l}\text { CAP: } \\
\text { Seftarolin } v s \\
\text { Seftriakson } \\
\text { ABSSSi: } \\
\text { Seftarolin } v s \\
\text { Vankomisin } \\
\text { atau } \\
\text { Sefazolin }\end{array}$ & $\begin{array}{l}\text { 1. Tingkat kesembuhan klinis pada } \\
\text { EOT dan TOC tidak berbeda secara } \\
\text { signifikan antara kelompok pasien } \\
\text { yang mendapat seftarolin } \\
\text { dibandingkan kelompok kontrol } \\
\text { dengan nilai OR 1,93 (95\% CI 0,88- } \\
\text { 4,25) dan } 1,36 \text { (95\% CI 0,64-2,91), } \\
\text { secara berturut-turut. } \\
\text { 2. Tingkat kegagalan klinis pada EOT } \\
\text { dan TOC tidak berbeda secara } \\
\text { signifikan antara kelompok pasien } \\
\text { yang mendapat seftarolin } \\
\text { dibandingkan kelompok kontrol } \\
\text { dengan nilai OR 0,62 (95\% CI 0,22- } \\
\text { 1,76) dan 0,68 (95\% CI 0,24-1,91), } \\
\text { secara berturut-turut }\end{array}$ \\
\hline $\begin{array}{l}\text { Hajj et al } \\
(2016)\end{array}$ & $3 \mathrm{RCT}$ & $\begin{array}{l}\text { Pasien } \\
\text { cSSSI } \\
\text { dewasa }\end{array}$ & $\begin{array}{l}\text { 2 RCT: } \\
\text { Seftarolin } v s \\
\text { Vankomisin } \\
\text { kombinasi } \\
\text { dengan } \\
\text { Aztreonam }\end{array}$ & $\begin{array}{l}\text { 1. Kesembuhan secara klinis pada } \\
\text { kelompok pasien yang memperoleh } \\
\text { seftarolin tidak berbeda secara } \\
\text { signifikan dibandingkan dengan } \\
\text { kelompok pasien yang mendapatkan } \\
\text { vankomisin dengan maupun tanpa } \\
\text { aztreonam (RR } 1,01 ; 95 \% \text { CI } 0,97-\end{array}$ \\
\hline
\end{tabular}




\begin{tabular}{|c|c|c|c|c|}
\hline $\begin{array}{c}\text { Pengarang } \\
\text { (tahun) }\end{array}$ & $\begin{array}{c}\text { Jumlah } \\
\text { penelitian }\end{array}$ & Populasi & Terapi & Luaran penelitian \\
\hline & & & $\begin{array}{l}\text { 1 RCT: } \\
\text { Seftarolin } v s \\
\text { Vankomisin } \\
\text { baik dengan } \\
\text { maupun } \\
\text { tanpa } \\
\text { Aztreonam }\end{array}$ & $\begin{array}{l}\text { 1,05) } \\
\text { 2. Kematian akibat cSSSI tidak berbeda } \\
\text { secara signifikan antara pasien yang } \\
\text { memperoleh terapi seftarolin } \\
\text { dibandingkan pasien yang } \\
\text { mendapatkan vankomisin dengan } \\
\text { maupun tanpa aztreonam (RR } 6,92 ; \\
95 \% \text { CI } 0,36-133,49)\end{array}$ \\
\hline $\begin{array}{l}\text { Lan et al } \\
\text { (2019) }\end{array}$ & $5 \mathrm{RCT}$ & $\begin{array}{l}\text { Pasien } \\
\text { cSSSI } \\
\text { dewasa }\end{array}$ & $\begin{array}{l}3 \text { RCT: } \\
\text { Seftarolin } v s \\
\text { Vankomisin } \\
\text { kombinasi } \\
\text { dengan } \\
\text { Aztreonam } \\
1 \text { RCT: } \\
\text { Seftarolin } v s \\
\text { Vankomisin } \\
\text { baik dengan } \\
\text { maupun } \\
\text { tanpa } \\
\text { Aztreonam } \\
1 \text { RCT: } \\
\text { Seftarolin } v s \\
\text { Vankomisin } \\
\pm \text { Seftriakson } \\
\pm \\
\text { metronidazol } \\
\text { atau } \\
\text { ampisilin/ } \\
\text { subaktam }\end{array}$ & $\begin{array}{l}\text { 1. Tingkat kesembuhan secara klinis } \\
\text { tidak berbeda secara signifikan } \\
\text { antara kelompok pasien dengan terapi } \\
\text { seftarolin dibandingkan kelompok } \\
\text { control dengan nilai RR sebagai } \\
\text { berikut: } \\
\text { a. Hasil analisis pada populasi } \\
\text { MITT = 1,00 (95\% CI 0,97- } \\
\text { 1,04) } \\
\text { b. Hasil analisis pada populasi CE } \\
=1,00 \text { (95\% CI 0,97-1,03) } \\
\text { 2. Efektivitas Seftarolin tidak berbeda } \\
\text { secara signifikan dibandingkan } \\
\text { dengan pembanding pada kasus } \\
\text { infeksi yang disebabkan oleh } \\
\text { a. Staphylococcus aureus (RR } \\
\text { 1,01; 95\% CI 0,98-1,05), } \\
\text { b. MRSA (RR 0,99; 95\% CI 0,94- } \\
\text { 1,05), } \\
\text { c. MSSA (RR 1,01; 95\% CI 0,96- } \\
\text { 1,06), } \\
\text { d. Streptococcus spp (RR 1,07; } \\
\text { 95\% CI 0,92-1,24), } \\
\text { e. bakteri gram negatif (RR 0,94; } \\
\text { 95\% CI 0,83-1,08) }\end{array}$ \\
\hline
\end{tabular}

Keterangan Tabel 3:

*dari total 14 penelitian hanya 8 penelitian yang memaparkan perbandingan antara seftarolin dan antibiotik lain, sedangkan 6 yang lain tidak memaparkan adanya antibiotik pembanding. Ditinjau dari desain penelitian, dari total 14 penelitian, 6 penelitian RCT, 1 case control, 5 kohort retrospektif, 1 penelitian observasional retrospektif, 1 retrospektif analisis dari sebuah penelitian.

\pm dengan atau tanpa kombinasi, ABSSSi: acute bacterial skin and skin structure infections, CABP: community-acquired bacterial pneumonia, CAP: community-acquired pneumonia, CE: clinical evaluable, CI: confidence intervals, cSSSI: chronic skin and soft tissue infections, EOT: end of therapy, HAP: hospital-acquired pneumonia, HCAP: health care-associated pneumonia, MDR: multiple drug resistant, ME: microbiologically evaluable, MITT: modified intention to treat, MRSA: methicillin-resistant Staphylococcus aureus, MSSA: methicillin-sensitive Staphylococcus aureus, OR: odds ratio, PORT: pneumonia outcome research team, RCT: randomized controlled trial, RR: relative risk, TOC: test of cure, VAP: ventilator-associated pneumonia 


\section{KEAMANAN PENGGUNAAN SEFTAROLIN}

Seftarolin terbukti memiliki profil keamanan yang tidak berbeda secara signifikan dibandingkan dengan antibiotik pembanding. Risiko kejadian ROTD ringan, sedang, dan berat pada pasien CABP yang memperoleh seftarolin tidak berbeda signifikan bila dibandingkan dengan pasien yang memperoleh seftriakson (Chen et al., 2019; Hajj et al., 2017; Lan et al., 2019). Pada kasus ABSSSi/SSTi, beberapa kajian sistematis dan meta-analisis juga menunjukkan bahwa kejadian ROTD seftarolin tidak berbeda secara signifikan bila dibandingkan dengan terapi pembanding (Chen et al., 2019; Hajj et al., 2017; Lan et al., 2019). Detail kajian sistematik terkait keamanan penggunaan seftarolin pada pasien CABP dan ABSSSi/SSTi dapat dilihat pada tabel 4.

Tabel 4. Ringkasan Kajian Sistematik Terkait Keamanan Seftarolin pada Pasien CABP dan ABSSSi/ SSTi

\begin{tabular}{|c|c|c|c|c|}
\hline $\begin{array}{c}\text { Pengarang } \\
\text { (tahun) }\end{array}$ & $\begin{array}{l}\text { Jumlah } \\
\text { penelitian }\end{array}$ & Populasi & Terapi & Luaran penelitian \\
\hline $\begin{array}{l}\text { Sotgiu et al } \\
\quad(2018)\end{array}$ & $4^{\ddagger}$ & $\begin{array}{l}\text { Pasien } \\
\text { CAP, } \\
\text { HAP, } \\
\text { VAP, } \\
\text { HCAP }\end{array}$ & $\begin{array}{l}\text { Seftarolin } v s \\
\text { Seftriakson atau } \\
\text { Vankomisin } \pm \\
\text { Linezolid }\end{array}$ & $\begin{array}{l}\text { Persentase kejadian berbagai macam } \\
\text { ROTD pada kelompok pasien dengan } \\
\text { terapi seftarolin dibandingkan dengan } \\
\text { (vs) kelompok kontrol adalah sebagai } \\
\text { berikut: } \\
\text { a. ROTD secara keseluruhan: } 39,9- \\
\text { 53,7\% vs } 42,7-47,2 \% \\
\text { b. Diare: } 3,8-6,3 \% \text { vs } 2,3-3,4 \% \\
\text { c. Sakit kepala: } 1,6-3,5 \% \text { vs } 1,3- \\
\text { 2,4\% } \\
\text { d. Insomnia: } 3,0-3,2 \% \text { vs } 1,9-2,6 \% \\
\text { e. Mual: } 1,9-2,7 \% \text { vs } 0,8-2,6 \% \\
\text { f. Flebitis: } 2,3-3,2 \% \text { vs } 1,6-2,6 \% \\
\text { g. Hipertensi: } 2,0-2,5 \% \text { vs } 2,6 \% \\
\text { h. Hipokalemi: } 1,3-3,2 \% \text { vs } 1,1- \\
\text { 3,2\% }\end{array}$ \\
\hline $\begin{array}{l}\text { Lan et al } \\
\text { (2019) }\end{array}$ & $5 \mathrm{RCT}$ & $\begin{array}{l}3 \quad \mathrm{RCT} \\
\text { pasien } \\
\text { CABP } \\
\text { dewasa } \\
\text { dan 2 RCT } \\
\text { pasien } \\
\text { CABP } \\
\text { anak-anak }\end{array}$ & $\begin{array}{l}\text { Seftarolin } v s \\
\text { Seftriakson }\end{array}$ & $\begin{array}{l}\text { Profil keamanan penggunaan } \\
\text { seftarolin tidak berbeda secara } \\
\text { signifikan dibandingkan seftriakson } \\
\text { dengan nilai OR sebagai berikut: } \\
\text { a. Jumlah pasien yang } \\
\text { membutuhkan terapi tambahan } \\
\text { untuk mengatasi ROTD = 0,99 } \\
\text { (95\% CI 0,75-1,30) } \\
\text { b. Kejadian ROTD dengan tingkat } \\
\\
\text { keparahan ringan = 1,08 (95\% } \\
\text { CI 0,69-1,70) } \\
\text { c. Kejadian ROTD dengan tingkat } \\
\text { keparahan sedang = 0,84 (95\% } \\
\text { CI 0,63-1,11) } \\
\text { d. Kejadian ROTD dengan tingkat } \\
\text { keparahan berat =0,87 (95\% CI } \\
\text { 0,56-1,34) } \\
\text { e. Jumlah pasien yang berhenti } \\
\text { menggunakan terapi akibat }\end{array}$ \\
\hline
\end{tabular}




\begin{tabular}{|c|c|c|c|c|}
\hline $\begin{array}{c}\text { Pengarang } \\
\text { (tahun) }\end{array}$ & $\begin{array}{c}\text { Jumlah } \\
\text { penelitian }\end{array}$ & Populasi & Terapi & Luaran penelitian \\
\hline & & & & $\begin{array}{ll} & \text { ROTD = 1,14 (95\% CI 0,67- } \\
& 1,96) \\
\text { f. } & \text { Kejadian ROTD serius = 0,95 } \\
& (95 \% \text { CI 0,67-1,34) }\end{array}$ \\
\hline $\begin{array}{l}\text { Hajj et al } \\
\text { (2016) }\end{array}$ & $3 \mathrm{RCT}$ & $\begin{array}{l}\text { Pasien } \\
\text { CAP } \\
\text { dewasa }\end{array}$ & $\begin{array}{l}\text { Seftarolin } v s \\
\text { Seftriakson }\end{array}$ & 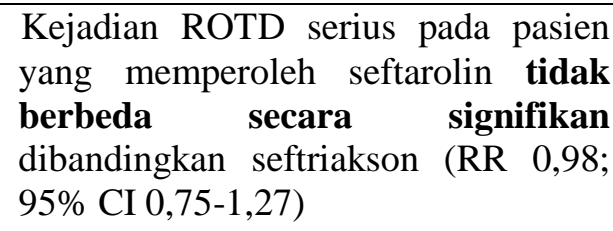 \\
\hline $\begin{array}{l}\text { Chen et al } \\
\text { (2019) }\end{array}$ & $\begin{array}{l}3 \\
\text { randomize } \\
\text { d study }\end{array}$ & $\begin{array}{l}\text { Pasien } \\
\text { pediatrik } \\
\text { CAP }(2 \\
\text { studi) dan } \\
\text { ABSSSi }\end{array}$ & $\begin{array}{l}\text { CAP: Seftarolin } \\
\text { vs Seftriakson } \\
\text { ABSSSi: } \\
\text { Seftarolin vs } \\
\text { Vankomisin atau } \\
\text { Sefazolin }\end{array}$ & $\begin{array}{l}\text { Kejadian ROTD antara seftarolin } \\
\text { tidak berbeda secara signifikan } \\
\text { dibandingkan antibiotik pembanding } \\
\text { dengan OR sebagai berikut: } \\
\text { a. Jumlah pasien yang } \\
\text { membutuhkan terapi untuk } \\
\text { ROTD = 0,81 (95\% CI 0,37- } \\
\text { 1,78) } \\
\text { b. Kejadian ROTD dengan tingkat } \\
\text { keparahan ringan = } 0,90 \text { (95\% } \\
\text { CI 0,54-1,51), } \\
\text { c. Kejadian ROTD dengan tingkat } \\
\text { keparahan sedang = 1,02 (95\% } \\
\text { CI 0,42-2,48) } \\
\text { d. Kejadian ROTD dengan tingkat } \\
\text { keparahan berat =0,66 (95\% CI } \\
\text { 0,19-2,27) } \\
\text { e. Jumlah pasien yang berhenti } \\
\text { menggunakan terapi akibat } \\
\text { ROTD = 1,44 (95\% CI 0,38- } \\
\text { 5,51) } \\
\text { f. Kejadian ROTD serius = 1,09; } \\
\text { (95\% CI 0,22-5,44) }\end{array}$ \\
\hline $\begin{array}{l}\text { Hajj et al } \\
\text { (2016) }\end{array}$ & $3 \mathrm{RCT}$ & $\begin{array}{l}\text { Pasien } \\
\text { cSSSI } \\
\text { dewasa }\end{array}$ & $\begin{array}{l}\text { 2 RCT: } \\
\text { Seftarolin } v s \\
\text { Vankomisin }+ \\
\text { Aztreonam } \\
1 \mathrm{RCT} \text { : } \\
\text { Seftarolin } v s \\
\text { Vankomisin } \pm \\
\text { Aztreonam }\end{array}$ & 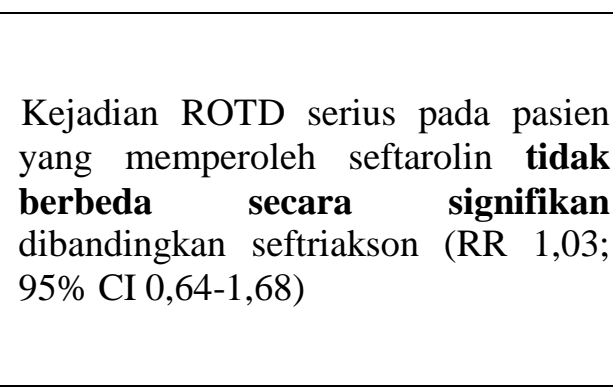 \\
\hline $\begin{array}{c}\text { Lan et al } \\
\text { (2019) }\end{array}$ & $5 \mathrm{RCT}$ & $\begin{array}{l}\text { Pasien } \\
\text { cSSSI } \\
\text { dewasa }\end{array}$ & $\begin{array}{l}\text { 3 RCT: } \\
\text { Seftarolin } v s \\
\text { Vankomisin }+ \\
\text { Aztreonam } \\
\text { 1 RCT: }\end{array}$ & $\begin{array}{l}\text { Profil keamanan penggunaan } \\
\text { seftarolin tidak berbeda secara } \\
\text { signifikan dibandingkan seftriakson } \\
\text { dengan nilai OR sebagai berikut: } \\
\text { a. Jumlah pasien yang } \\
\text { membutuhkan terapi untuk }\end{array}$ \\
\hline
\end{tabular}




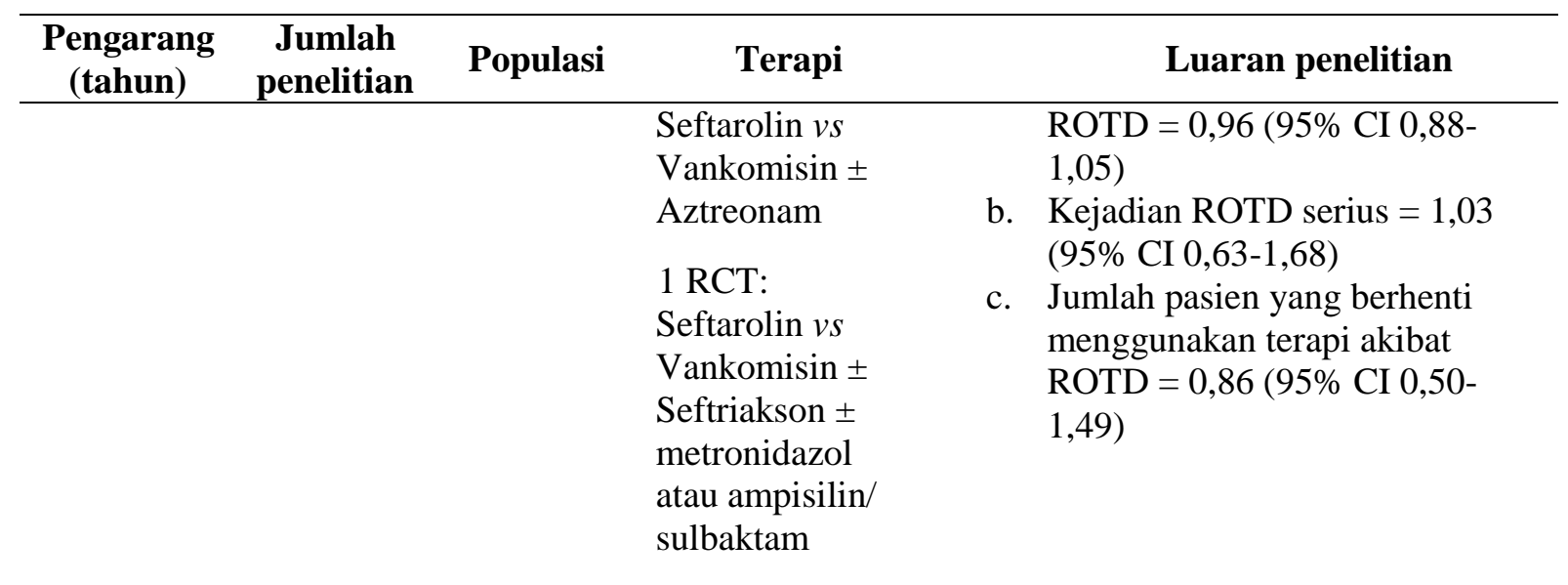

Keterangan Tabel 4:

$\$ 4$ penelitian RCT yang membandingkan Seftarolin dengan Seftriakson pada pasien CABP, \pm dengan atau tanpa kombinasi, ABSSSi: acute bacterial skin and skin structure infections, CABP: communityacquired bacterial pneumonia, CAP: community-acquired pneumonia, CI: confidence intervals, cSSSI: chronic skin and soft tissue infections, HAP: hospital-acquired pneumonia, HCAP: health care-associated pneumonia, OR: odds ratio, RCT: randomized controlled trial, ROTD: reaksi obat yang tidak dikehendaki, RR: relative risk, VAP: ventilator-associated pneumonia

\section{BIAYA PENGGUNAAN}

Biaya penggunaan seftarolin untuk terapi CABP maupun ABSSSi/SSTi cenderung lebih besar dibandingkan biaya terapi menggunakan antibiotik lainnya. Pada artikel ini, sebuah pustaka digunakan sebagai referensi standar untuk mendapatkan informasi terkait harga antibiotik (Santoso et al., 2018). Apabila tidak ditemukan informasi harga antibiotik pada referensi tersebut, maka informasi dari sebuah rumah sakit swasta akan digunakan sebagai acuan. Regimen dosis yang digunakan pada tabel didasarkan pada beberapa pustaka acuan (American society of health-system pharmacist, 2018; European Medicines Agency, 2019; Food and Drug Administration, 2012; Metlay et al., 2019; Stevens et al., 2014; Therapeutic Goods Administration Health Safety Regulation, 2013). Detail perbandingan harga dan biaya untuk 1 siklus pengobatan dapat dilihat pada tabel 5.

Tabel 5. Perbandingan Harga dan Biaya Penggunaan Seftarolin untuk CABP dan ABSSSi/SSTi

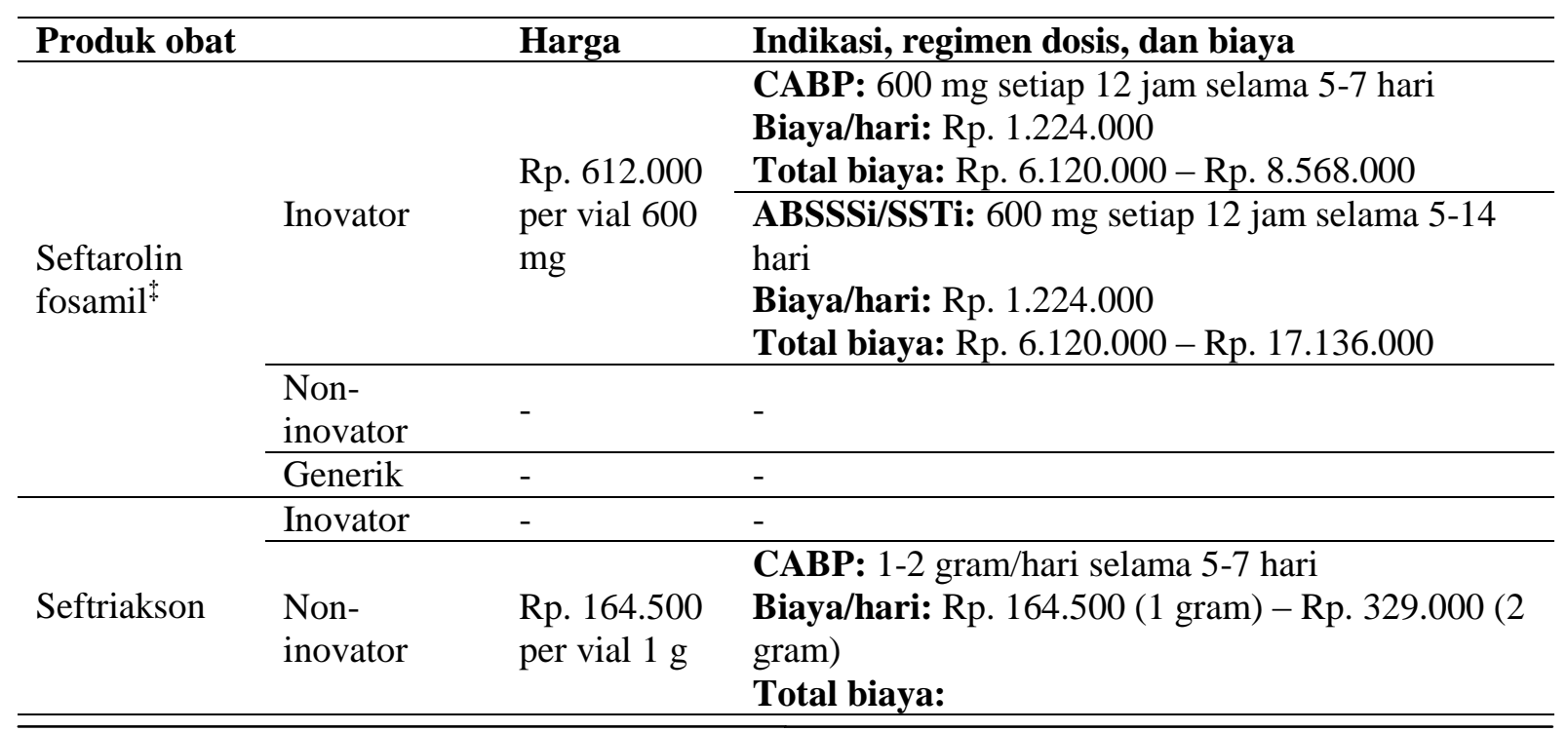




\begin{tabular}{|c|c|c|c|}
\hline \multicolumn{2}{|l|}{ Produk obat } & \multirow[t]{2}{*}{ Harga } & \multirow{2}{*}{$\begin{array}{l}\text { Indikasi, regimen dosis, dan biaya } \\
\text { - Regimen } 1 \text { gram/hari: Rp. } 822.500-\mathrm{Rp} . \\
\text { 1.151.500 } \\
\text { - Regimen } 2 \text { gram/hari: Rp. } 1.645 .000-\text { Rp. } \\
\text { 2.303.000 }\end{array}$} \\
\hline & & & \\
\hline & Generik $^{\dagger}$ & $\begin{array}{l}\text { Rp. } 14.125 \\
\text { per vial } 1 \mathrm{~g}\end{array}$ & $\begin{array}{l}\text { CABP: } 1 \text {-2 gram/hari selama 5-7 hari }{ }^{44} \\
\text { Biaya/hari: Rp. } 14.125 \text { (1 gram) - Rp. } 28.250(2 \\
\text { gram) } \\
\text { Total biaya: } \\
\quad \text { - Regimen } 1 \text { gram/hari: Rp. } 70.625 \text { - Rp. } 98.875 \\
\text { - Regimen } 2 \text { gram/hari: Rp. } 141.250-\text { Rp. } \\
\quad 197.750\end{array}$ \\
\hline \multirow{3}{*}{ Sefotaksim } & Inovator & - & - \\
\hline & $\begin{array}{l}\text { Non- } \\
\text { inovator }\end{array}$ & $\begin{array}{l}\text { Rp. } 111.000 \\
\text { per vial } 1 \mathrm{~g}\end{array}$ & $\begin{array}{l}\text { CABP: } 1-2 \text { gram/8 jam selama 5-7 hari } \\
\text { Biaya/hari: Rp. } 333.000 \text { (1 gram) - Rp. } 666.000 \text { (2 } \\
\text { gram) } \\
\text { Total biaya: } \\
\text { - Regimen } 1 \text { gram/hari: Rp. } 1.665 .000-\text { Rp. } \\
\quad 2.331 .000 \\
\text { - Regimen } 2 \text { gram/hari: Rp. } 3.330 .000-\text { Rp. } \\
\quad \text { 4.662.000 }\end{array}$ \\
\hline & Generik $^{\ddagger}$ & $\begin{array}{l}\text { Rp. } 9.280 \\
\text { per vial } 1 \mathrm{~g}\end{array}$ & $\begin{array}{l}\text { CABP: 1-2 gram/8 jam selama 5-7 hari } \\
\text { Biaya/hari: Rp. } 27.840 \text { (1 gram) - Rp. } 55.680 \text { (2 } \\
\text { gram) } \\
\text { Total biaya: } \\
\text { - Regimen } 1 \text { gram/hari: Rp. } 139.200-\text { Rp. } \\
\quad 194.880 \\
\text { - Regimen } 2 \text { gram/hari: Rp. } 278.400-\text { Rp. } \\
\quad 389.760\end{array}$ \\
\hline \multirow{3}{*}{ Levofloksasin } & Inovator & - & - \\
\hline & $\begin{array}{l}\text { Non- } \\
\text { inovator }\end{array}$ & $\begin{array}{l}\text { Rp. } 290.000 \\
\text { per kantong } \\
\text { infus } 750 \mathrm{mg}\end{array}$ & $\begin{array}{l}\text { CABP: } 750 \mathrm{mg} / \text { hari selama } 5-7 \text { hari } \\
\text { Biaya/hari: Rp. } 290.000 \\
\text { Total biaya: Rp. } 1.450 .000 \text { - Rp. } 2.030 .000\end{array}$ \\
\hline & Generik $^{*}$ & $\begin{array}{l}\text { Rp. } 58.700 \\
\text { per vial } 500 \\
\text { mg }\end{array}$ & $\begin{array}{l}\text { CABP: } 750 \mathrm{mg} / \text { hari selama } 5-7 \text { hari } \\
\text { Biaya/hari: } \mathrm{Rp} .117 .400(2 \mathrm{vial}) \\
\text { Total biaya: } \mathrm{Rp} .587 .000 \text { - Rp. } 821.000\end{array}$ \\
\hline \multirow{3}{*}{$\begin{array}{l}\text { Amoksisilin- } \\
\text { klavulanat }\end{array}$} & Inovator & - & - \\
\hline & $\begin{array}{l}\text { Non- } \\
\text { inovator }\end{array}$ & $\begin{array}{l}\text { Rp. } 89.000 \\
\text { per vial } 1 \mathrm{~g}\end{array}$ & $\begin{array}{l}\text { CABP: } 2000 / 125 \text { mg setiap } 12 \text { jam selama 5-7 hari } \\
\text { Biaya/hari: Rp. } 356.000 \\
\text { Total biaya: } R \text { p. } 1.780 .000 \text { - Rp. } 2.492 .000\end{array}$ \\
\hline & Generik & - & - \\
\hline \multirow{3}{*}{ Vankomisin } & Inovator & - & - \\
\hline & $\begin{array}{l}\text { Non- } \\
\text { inovator }\end{array}$ & $\begin{array}{l}\text { Rp. } 180.000 \\
\text { per vial } 500 \\
\text { mg }\end{array}$ & $\begin{array}{l}\text { ABSSSi/SSTi: } 15 \mathrm{mg} / \mathrm{kg} \text { setiap } 12 \text { jam selama } 7-14 \\
\text { hari (misal BB } 60 \mathrm{~kg}=900 \mathrm{mg} \text { setiap } 12 \text { jam) } \\
\text { Biaya/hari: } \mathrm{Rp} .720 .000 \\
\text { Total biaya: } \text { Rp. } 5.040 .000-\text { Rp. } 10.080 .000\end{array}$ \\
\hline & Generik $^{\ddagger}$ & $\begin{array}{l}\text { Rp. } 279.330 \\
\text { per vial } 500 \\
\text { mg }\end{array}$ & $\begin{array}{l}\text { ABSSSi/SSTi: } 15 \mathrm{mg} / \mathrm{kg} \text { setiap } 12 \text { jam selama } 7-14 \\
\text { hari (misal BB } 60 \mathrm{~kg}=900 \mathrm{mg} \text { setiap } 12 \text { jam) } \\
\text { Biaya/hari: } \mathrm{Rp} .1 .117 .000 \\
\text { Total biaya: } \text { Rp. } 7.821 .240-\text { Rp. } 15.642 .480\end{array}$ \\
\hline Linezolid & Inovator & Rp. 594.669 & ABSSSi/SSTi: 600 mg/12 jam selama 7-14 hari \\
\hline
\end{tabular}




\begin{tabular}{|c|c|c|c|}
\hline \multirow[t]{4}{*}{ Produk obat } & & Harga & Indikasi, regimen dosis, dan biaya \\
\hline & & $\begin{array}{l}\text { per vial } 600 \\
\text { mg }\end{array}$ & $\begin{array}{l}\text { Biaya/hari: Rp. } 1.189 .338 \\
\text { Total biaya: } R \text {. } 8.325 .366 \text { - Rp. } 16.650 .732\end{array}$ \\
\hline & $\begin{array}{l}\text { Non- } \\
\text { inovator }\end{array}$ & - & 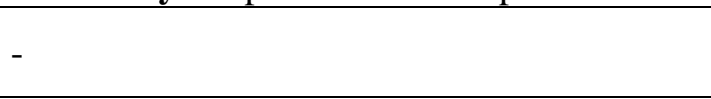 \\
\hline & Generik & - & - \\
\hline
\end{tabular}

Keterangan Tabel 5.

"Informasi harga diperoleh dari sebuah rumah sakit swasta di Surabaya dengan mempertimbangkan harga belum terdapat di referensi rujukan.

ABSSSi: acute bacterial skin and skin structure infections, BB: berat badan, CABP: communityacquired bacterial pneumonia, SSTi: skin and soft tissue infection.

\section{KESIMPULAN}

Sebagai antibiotik baru, seftarolin memiliki peran penting dalam tata laksana penyakit infeksi CABP dan ABSSSi/SSTi, khususnya yang disebabkan oleh MRSA. Namun demikian, tidak dapat diasumsikan bahwa seftarolin selalu lebih efektif dibandingkan dengan antibiotik lain pada setiap kasus infeksi CABP dan ABSSSi/SSTi. Ditinjau dari aspek keamanan penggunaan, seftarolin memiliki profil kemanan yang tidak berbeda bermakna secara signifikan dibandingkan dengan antibiotik pembanding. Tidak demikian halnya dengan aspek biaya, dimana biaya penggunaan seftarolin lebih tinggi dibandingkan dengan antibiotik pembanding. Oleh karena itu. strategi pengawalan penggunaan seftarolin (stewardship program) perlu diupayakan agar keseimbangan keberhasilan dan keamanan penggunaan seftarolin dapat dioptimalkan.

\section{DAFTAR PUSTAKA}

American society of health-system pharmacist. (2018). AHFS drug information. Canada: American Society of Health-System Pharmacists, Inc.

Beauduy, C., \& Winston, L. (2018). Beta-lactam \& other cell wall \& membrane-active antibiotics. In B. Katzung (Ed.), Basic \& Clinical Pharmacology (14th ed, pp. 795-814). North America: McGraw-Hill Companies, Inc.

Bhavnani, S., Hammel, J., Van Wart, S., Rubino, C., Reynolds, D., Forrest, A., ... Friedland, H. (2013). Pharmacokinetic-pharmacodynamic analyses for efficacy of ceftaroline fosamil in patients with community-acquired bacterial pneumonia. Antimicrob Agents Chemother, 57(12), 6348-6350.

Cano, E., Haque, N., Welch, V., Cely, C., Peyrani, P., Scerpella, E., ... Zervos, M. (2012). Incidence of nephrotoxicity and association with vancomycin use in intensive care unit patients with pneumonia: retrospective analysis of the IMPACT-HAP database. Clin Ther, 34(1), 149-157.

Canut, A., Isla, A., Betriu, C., \& Gascón, A. (2012). Pharmacokinetic-pharmacodynamic evaluation of daptomycin, tigecycline, and linezolid versus vancomycin for the treatment of MRSA infections in four western European countries. Eur J Clin Microbiol Infect Dis, 3(9), 2227-2235.

Centers for Disease Control. (2013). Centers for Disease Control and Prevention, Office of Infectious Disease Antibiotic resistance threats in the United States. Retrieved November 28, 2019, from http://www.cdc.gov/drugresistance/ threat-report-2013

Chen, Chih-wei, Chang, S., Huang, H., Tang, H., \& Lai, C. (2019). The efficacy and safety of ceftaroline in the treatment of acute bacterial infection in pediatric patients - a systemic review and meta-analysis of randomized controlled trials. Infection and Drug Resistance, 12, 13031310 . 
Chen, CJ, \& Huang, Y. (2014). New epidemiology of Staphylococcus aureus in Asia. Clin Microbiol Infect, 20(7), 605-623.

Chou, C., Shen, C., Chen, S., Chen, H., Wang, Y., Chang, W., ... Chen, W. (2019). Recommendations and guidelines for the treatment of pneumonia in Taiwan. Journal of Microbiology, Immunology and Infection, 52, 172-199.

Craig, W., \& Andes, D. (2015). Cephalosporins. In J. Bennett, R. Dolin, \& M. Blaser (Eds.), Principles and practice of infectious diseases (8th ed, pp. 278-292). Canada: Elsevier Inc.

Das, S., Li, J., Iaconis, J., Zhou, D., Stone, G., Yan, J., \& Melnick, D. (2019). Ceftaroline fosamil doses and breakpoints for Staphylococcus aureus in complicated skin and soft tissue infections. J Antimicrob Chemother, 74(2), 425-431.

Devleesschauwer, B., de Noordhout, C., Smit, G., Duchateau, L., Dorny, P., Stein, C., ... Speybroeck, N. (2014). Quantifying burden of disease to support public health policy in Belgium: opportunities and constraints. BMC Public Health, 14(1196), 1-8.

Ding, J., Sun, Q., Li, K., Zheng, M., Miao, X., Ni, W., ... Yang, J. (2009). Retrospective analysis of nosocomial infections in the intensive care unit of a tertiary hospital in China during 2003 and 2007. BMC Infect Dis, 9(115).

Dong, Y., Chbat, N., Gupta, A., Hadzikadic, M., \& Gajic, O. (2012). Systems modelling and simulation applications for critical care medicine. Ann Intensive Care, 2(1), 18.

Doyle, J., Buising, K., Thursky, K., Worth, L., \& Richards, M. (2011). Epidemiology of infections acquired in intensive care units. Semin Respir Crit Care Med, 32(2), 115-138.

European Committee on Antimicrobial Susceptibility Testing. (n.d.). Antimicrobial wild type distributions of microorganisms. Retrieved November 20, 2019, from http://mic.eucast.org/Eucast2/SearchController/search.jsp?action=performSearch\&BeginIndex= $0 \&$ Micdif $=$ mic $\&$ NumberIndex $=50 \&$ Antib $=38 \&$ Specium $=-1$

European Medicines Agency. (2019). Zinforo: summary of product characteristic. Retrieved November 10, 2019, from https://www.ema.europa.eu/en/documents/productinformation/zinforo-epar-product-information_en.pdf

Food and Drug Administration. (2012). Teflaro (ceftaroline fosamil) injection. Retrieved November 10, 2019, from https://www.accessdata.fda.gov/drugsatfda_docs/nda/2010/200327orig1s000toc.cfm

Gallagher, J., \& MacDougall, C. (2018). Antibiotics simplified (4th ed). Philadelphia: Jones \& Bartlett Learning.

GBD 2015 and HALE Collborators. (2016). Global, regional, and national disability-adjusted lifeyears (DALYs) for 315 diseases and injuries and healthy life expectancy (HALE), 1990-2015: a systematic analysis for the Global Burden of Disease Study 2015. Lancet, 388, 1603-1658.

Golan, Y. (2019). Current Treatment Options for Acute Skin and Skin- structure Infections. Clinical Infectious Diseases, 68(S3), S206-12.

Hajj, M., Turgeon, R., \& Wilby, K. (2017). Ceftaroline fosamil for community-acquired pneumonia and skin and skin structure infections: a systematic review. International Journal of Clinical Pharmacy. 
Jorgensen, J., \& Ferraro, M. (2009). Antimicrobial susceptibility testing: a review of general principles and contemporary practices. Clinical Infectious Diseases, 49, 1749-1755.

Kmietowicz, Z. (2017). Few novel antibiotics in the pipeline, WHO warns. BMJ, 358(j4339).

Kullar, R., Davis, S., Levine, D., \& Rybak, M. (2011). Impact of vancomycin exposure on outcomes in patients with methicillin-resistant Staphylococcus aureus bacteremia: support for consensus guidelines suggested targets. Clin Infect Dis, 52(8), 975-981.

Kuti, K. (2016). Optimizing antimicrobial pharmacodynamics: a guide for your stewardship program. Rev Med Clin Condes, 27(5), 615-624.

Lan, S., Chang, S., Lai, C., \& Lu, L. (2019). Ceftaroline Efficacy and Safety in Treatment of Complicated Skin and Soft Tissue Infection: A Systemic Review and Meta-Analysis of Randomized Controlled Trials. Journal of Clinical Medicine, 8(776), 1-10.

Lan, S., Chang, S., Lai, C., Lu, L., \& Chao, C. (2019). Efficacy and Safety of Ceftaroline for the Treatment of Community-Acquired Pneumonia: A Systemic Review and Meta-Analysis of Randomized Controlled Trials. Journal of Clinical Medicine, 8(824).

Li, J., Das, S., Zhou, D., \& Al-Huniti, N. (2019). Population Pharmacokinetic Modeling and Probability of Target Attainment Analyses in Asian Patients With Community-Acquired Pneumonia Treated With Ceftaroline Fosamil. Clin Pharmacol Drug Dev, 8(5), 682-694.

Liu, C., Bayer, A., Cosgrove, S., Daum, R., Fridkin, S., Gowritz, R., ... Karchmer, A. (2011). Clinical practice guidelines by the Infectious Diseases Society of America for the treatment of methicillin-resistant Staphylococcus aureus infections in adults and children. Clin Infect Dis, $52(3), 18-55$.

Lobanovska, M., \& Pilla, G. (2017). Penicillin's discovery and antibiotic resistance: lessons for the future? Yale J Biol Med, 90(1), 135-145.

Metlay, J. P., Waterer, G. W., Long, A. C., Anzueto, A., Brozek, J., Crothers, K., ... Musher, D. M. (2019). Diagnosis and Treatment of Adults with Community-acquired Pneumonia: an Official Clinical Practice Guideline of the American Thoracic Society and Infectious Diseases Society of America. American Thoracic Society, 200(7). https://doi.org/10.1164/rccm.201908-1581ST

Minejima, E., Choi, J., Beringer, P., Lou, M., Tse, E., \& Wong-Beringer, A. (2011). Applying new diagnostic criteria for acute kidney injury to facilitate early identification of nephrotoxicity in vancomycin-treated patients. Antimicrob Agents Chemother, 55(7), 3278-3283.

Moore, C., Osaki-Kiyan, P., Haque, N., Perri, M., Donabedian, S., \& Zervos, M. (2011). Daptomycin versus vancomycin for bloodstream infections due to methicillin-resistant Staphylococcus aureus with a high vancomycin minimum inhibitory concentration: a case-control study. Clin Infect Dis, 54(1), 51-58.

National Institute for Health and Care Excellence. (2019). Pneumonia (community-acquired): antimicrobial prescribing. NICE Guideline, 1-30.

O'Neill, J. (2014). Antimicrobial resistance: tackling a crisis for the health and wealth of nations. 2014. Retrieved November 20, 2019, from https://amr-review.org/sites/default/files/ AMR\%2520Review\%25 20Paper\%2520-\%2520Tackling\%2520a\%2520crisis\%2520for $\% 2520$ the $\% 2520$ health\%2520and\%2520wealth\%2520of\%2520nations_1.pdf

Onufrak, N., Forrest, A., \& Gonzalez, D. (2016). Pharmacokinetic and pharmacodynamic principles of 
anti-infective dosing. Clin Ther, 38(9), 1930-1947.

Pitz, A., Yu, F., Hermsen, E., Rupp, M., Fey, P., \& Olsen, K. (2011). Vancomycin susceptibility trends and prevalence of heterogeneous vancomycin-intermediate Staphylococcus aureus in clinical methicillin-resistant S. aureus isolates. J Clin Microbiol, 49(1), 269-274.

Pritchard, L., Baker, C., Leggett, J., Sehdev, P., Brown, A., \& Bayley, K. (2010). Increasing vancomycin serum trough concentrations and incidence of nephrotoxicity. Am J Med, 123(12), $1143-1149$.

Roberts, J., Abdul-Aziz, Lipman, J., Mouton, J., Vinks, A., Felton, T., ... Farkas, A. (2014). Individualised antibiotic dosing for patients who are critically ill: challenges and potential solutionso Title. Lancet Infect Dis, 14, 498-509.

Roberts, J., Kirkpatrick, C., \& Lipman, J. (2011). Monte Carlo simulations: maximizing antibiotic pharmacokinetic data to optimize clinical practice for critically ill patients. $J$ Antimicrob Chemother, 66(2), 227-231.

Rowland, M., \& Tozer, T. (2011). Clinical pharmacokinetics and pharmacodynamics: concepts and applications (4th ed). China: Lippincott Williams \& Wilkins.

Santoso, A., Pusponegoro, A., Sani, A., Rani, A., Lelo, A., Kartasasmita, C., ... Harimurti, G. (2018). MIMS referensi obat: informasi ringkas produk obat. Jakarta: PT. Bhuana Ilmu Populer (Kelompok Gramedia).

Sauermann, R., Rothenburger, M., Graninger, W., \& Joukhadar, C. (2008). Daptomycin: a review 4 years after first approval. Pharmacology, 81(2), 79-91.

Setiawan, E., \& Montakantikul, P. (2018). Pharmacokinetic and Pharmacodynamic Approach in Adult Critically-Ill Patients Treated with Standard Dose of Vancomycin for MRSA Infection. Journal of Medical Association of Thailand, 101(5), 555-562.

Setiawan, E., Suwannoi, L., Montakantikul, P., \& Chindavijak, B. (2019). Optimization of Intermittent Vancomycin Dosage Regimens for Thai Critically Ill Population Infected by MRSA in the Era of "MIC Creep" Phenomenon. Acta Medica Indonesiana - Indones J Intern Med, 51(1), 10-18.

Setiawan, E., Widyati, W., Marpaung, F., Sukandar, E., Susaniwati, S., Lukas, D., \& Wiyono, H. (2019). Narrative Review on Pharmacokinetics of Antibiotics among Critically Ill Patients: the Implication on the Pharmacokinetics-Pharmacodynamics Target Attainment. Pharmaceutical Sciences and Research, 6(1), 1-12.

Silverman, J., Mortin, L., Vanpraagh, A., Li, T., \& Alder, J. (2005). Inhibition of daptomycin by pulmonary surfactant: in vitro modeling and clinical impact. J Infect Dis, 191(12), 2149-2152.

Sotgiu, G., Aliberti, S., Gramegna, A., Mantero, M., Pasquale, M. Di, Trogu, F., ... Blasi, F. (2018). Efficacy and effectiveness of Ceftaroline Fosamil in patients with pneumonia: a systematic review and meta-analysis. Respiratory Research, 19(205), 1-13.

Spapen, H., Jansen van Doorn, K., Diltoer, M., Verbrugghe, W., Jacobs, R., Dobbeleir, N., ... Jorens, P. (2011). Retrospective evaluation of possible renal toxicity associated with continuous infusion of vancomycin in critically ill patients. Ann Intensive Care, 1(1), 26.

Stevens, D. L., Bisno, A. L., Chambers, H. F., Dellinger, E. P., Goldstein, E. J. C., Gorbach, S. L., ... Wade, J. C. (2014). Practice Guidelines for the Diagnosis and Management of Skin and Soft Tissue Infections: 2014 Update by the Infectious Diseases Society of America. Clinical 
Infectious Diseases, 99, 147-159.

Therapeutic Goods Administration Health Safety Regulation. (2013). Australian public assessment report for ceftaroline fosamil. Australia.

Tortora, G., Funke, B., \& Case, C. (2019). Antimicrobial drugs. In Microbiology: an introduction (13th ed, pp. 558-574). United State: Pearson Education, Inc.

Traebert, J., Nickel, D., Traebert, E., Escalante, J., \& Schneider, I. (2016). The burden of infectious diseases in the Brazilian Southern state of Santa Catarina. J Infect Public Health, 9(2), 181-191.

Tsering, D., Pal, R., \& Kar, S. (2011). Methicillin-Resistant Staphylococcus Aureus: prevalence and current susceptibility pattern in Sikkim. J Glob Infect Dis, 3(1), 9-13.

van Hal, S., Lodise, T., \& Paterson, D. (2012). The clinical significance of vancomycin minimum inhibitory concentration in Staphylococcus aureus infections: a systematic review and metaanalysis. Clin Infect Dis, 54(6), 755-771.

Van Lier, A., McDonald, S., Bouwknegt, M., Kretzscmar, M., Havelaar, A., Mangen, M., \& Wallinga, J. (2016). Disease burden of 32 infectious diseases in the Netherlands, 2007-2011. PLoS One, $11(4)$.

Vincent, J., Rello, J., Marshall, J., Silva, E., Anzueto, A., Martin, C., ... Lipman, J. (2009). International study of the prevalence and outcomes of infection in intensive care units. JAMA, 302(21), 2323-2329.

Wi, Y., Kim, J., Joo, E., Ha, Y., Kang, C., \& Ko, K. (2012). High vancomycin minimum inhibitory concentration is a predictor of mortality in methicillin-resistant Staphylococcus aureus bacteraemia. Int J Antimicrob Agents, 40(2), 108-113.

Wong-Beringer, A., Joo, J., Tse, E., \& Beringer, P. (2011). Vancomycin-associated nephrotoxicity: a critical appraisal of risk with high-dose therapy. Int J Antimicrob Agents, 37(2), 95-101.

World Health Organization. (2019). The 2019 WHO AWaRe classification of antibiotics for evaluation and monitoring of use. Retrieved November 10, 2019, from https://www.who.int/medicines/news/2019/WHO_releases2019AWaRe_classification_antibioti cs/en/

Yeh, Y., Yeh, K., Lin, T., Chiu, S., Yang, Y., Wang, Y., \& Lin, J. (2012). Impact of vancomycin MIC creep on patients with methicillin-resistant Staphylococcus aureus bacteremia. J Microbiol Immunol Infect, 45(3), 214-220.

Zhanel, G. G., Sniezek, G., Schweizer, F., Zelenitsky, S., Rubinstein, E., Gin, A. S., ... Karlowsky, J. A. (2009). Ceftaroline: a novel broad-spectrum cephalosporin with activity against methicillinresistant Stapylococcus aureus. Drugs, 69(7), 809-831. 